\title{
POSICIONAMENTOS DE AGAMBEM E JAKOBS EM MILAGRES NA CELA 7
}

\author{
Fernando Henrique da Silva Horita ${ }^{1}$
}

\section{RESUMO}

Através da produção cinematográfica turca Milagre na Cela 7 localiza-se posicionamentos de Agamben e Jakobs. Embora não seja um filme baseado em fatos reais, demonstra certas posições de ambos pensadores. O presente artigo tem como objetivo realizar algumas constatações conceituais do pensamento de Jakobs com o pensamento de Agamben em Milagre na Cela 7. O método foi o dedutivo e análise a bibliográfica, sendo a pesquisa qualitativa. O filme propiciou a conexão da posição teórica sobre o inimigo em Jakobs, bem como de homo sacer e estado de exceção em Agamben.

Palavras-chave: Direito Penal do Inimigo; Estado de Exceção; Giorgio Agamben; Günther Jakobs; Milagre na Cela 7.

\section{AGAMBEN AND JAKOBS POSITIONS IN MIRACLE IN CELL 7}

\begin{abstract}
Through the Turkish film production Miracle in Cell 7, positions of Agamben and Jakobs are located. Although it is not a film based on real events, it demonstrates certain positions of both thinkers. This article aims to make some conceptual findings of Jakobs' thought with Agamben's thought in Miracle in Cell 7. The method was deductive and bibliographic analysis, qualitative research. The film provided the connection between the theoretical position on the enemy in Jakobs, as well as the homo sacer and state of exception in Agamben.
\end{abstract}

Keywords: Criminal Law of the Enemy; Exception state; Giorgio Agamben; Günther Jakobs; Miracle in Cell 7.

\section{INTRODUÇÃO}

São tempos interessantes para constatar os posicionamentos de Jakobs sob o foco do controverso conceito de inimigo e Agamben perante sua abordagem sobre homo sacer e estado de exceção na produção cinematográfica turca Milagre na Cela 7. Embora identifica-se

\footnotetext{
${ }^{1}$ Docente de Direito na UNEMAT e FASIP. Especialista em Filosofia e Teoria do Direito pela PUC-MG. Mestre em Teoria do Direito e do Estado pelo UNIVEM. Doutorando em Filosofia pela UNISINOS. Endereço: Rua Sabarás, 1049, Jardim Belo Horizonte, CEP 78556-284, Sinop-MT. E-mail: profhorita@outlook.com
} 
uma dialética que não seja exclusiva desse filme, observou que essa produção poderia acrescentar discussão importante para a temática em razão das cenas ilustradas ao decorrer dele. Aliado a isto, é relevante o presente artigo estar centrado nessa relação jus-filosófica entre ambos os pensadores em razão de abrir caminhos para construir respostas à dilemas da realidade jurídica e social.

É preciso ter presente que a narrativa do filme traz uma história que se envolve com evidencias do estado qualificado pela exceção e que, não obstante, este permite a possibilidade de suspender os direitos e garantias fundamentais mesmo amparadas por uma regra jurídica.

Por sua vez, o direito penal do inimigo, cria uma distinção entre o cidadão, propondo um tratamento diferenciado ao inimigo, que seriam aqueles que são considerados como uma fonte de perigo ao contrato social. Logo, por meio dos posicionamentos de Giorgio Agamben e de Günther Jakobs enseja em ilustrar algumas cenas do filme realizando ao mesmo tempo uma construção do saber filosófico e jurídico.

A exceção é uma reflexão filosófica que representa singularidade, sabendo que ela se apresenta em torno da ordem e da civilidade estabelecidas, por intermédio dela pode-se dizer que a autoridade não precisa do direito para construção jurídica, basta-lhe o poder, dentre o qual se torna possível a eliminação do inimigo que pareça inintegrável ao sistema político. E é, exatamente nessa conjuntura que se apresentará a história de Memo. Nesses passos, o filme vai evidenciar que os cidadãos em sua totalidade podem estar sujeitos a essa questão, ao tempo que ficam situados dentro do ordenamento jurídico, também pode ocorrer de ficarem fora dele.

Os posicionamentos do filósofo italiano, Agamben, agrega questões teóricas das peculiaridades do estado de exceção apresentando uma série de detalhes importantes para compreensão do todo, podendo se deparar com o conceito de vida nua, vida está desqualificada pelo direito e com o de homo sacer, punição romana que ao longo da pesquisa se desenvolve sua conceituação. Dessa forma, a partir dos conhecimentos filosóficos desse autor, já se observa a magnitude de se aprofundar em seus posicionamentos.

Milagre na Cela 7guarda fortes relações com o direito penal do inimigo, teoria desenvolvida por Günther Jakobs. Esse direito penal adjetivado pelo inimigo pode ser interpretado como um direito penal de exceção. Assim, a opção por esse outro pensador na construção dialética com o filme, se justifica pela noção de inimigo que o filme transpassa, alcançando uma analogia às repercussões que essa teoria alcançou após o atentado de 11 de 
setembro de 2001 nos Estados Unidos e pela observância dessa temática na própria atualidade. Esses são alguns dos motivos que fazem exteriorizar que a vivência de Memo como inimigo é algo que deve ser debatida e realizada uma construção crítica. Assim esse diálogo não pode ser deixado apenas na ficção e sim criar pontos de reflexões.

Com efeito, essa opção pelo jus-filósofo Jakobs e por Agamben é ofertada em razão da pontualidade de seus pensamentos, qualificadas pela leitura dos acontecimentos do cotidiano que muito bem são representados no filme. Para tanto, essa pesquisa se direcionou a reflexões conceituais dos dois pensadores, entendendo por melhor que o método para alcançar o escopo perpassou pelo dedutivo centrado na interdisciplinaridade entre filosofia e direito, levando em consideração como procedimentos técnicos a pesquisa bibliográfica.

\section{1 - DE MEMO EM MILAGRE NA CELA 7 À AGAMBEN}

A produção cinematográfica turca Milagre na Cela 7 (2019) na qual é uma adaptação da produção sul-coreana (2013), Miracle in Cell No. 7 de Lee Hwan-gyeong, traz uma história que pode se relacionar muito bem com alguns posicionamentos de Agamben, por isso tendese revisar o filme através de alguns conceitos elucidados pelo filósofo italiano.

A vida de Memo que é o personagem principal dessa história tem um contexto ao redor de uma vila no mar Egeu em meados dos anos 80. Cabe mencionar que Memo é um homem com deficiência intelectual que é pastor e que é acusado injustamente de ter matado uma criança, sendo levado a cela número 7 e condenado a morte (MILAGRE NA CELA 7, 2019). Claro que esse enredo é apenas um resumo da história, mas cabe relatar alguns posicionamentos de Agamben (2014), entre eles, que destaca a forma paradigmática de todo ato de governo se referindo à um efeito colateral.

Por seu turno, Memo é acusado injustamente de ter cometido um homicídio da criança que o seguia (filha do tenente da cidade, e que por acidente acabou escorregando nas pedras, batendo a cabeça e tendo a consequência de seu falecimento) forçado a depor, assina sua confissão através de seu dedão na qual era segurado por guardas, tendo o resultado de sua condenação e por seguinte sua prisão. Essa cena no filme demonstra que a punição dada a Memo era algo primário, mas que ao longo do drama conteve efeitos mais amplos, não esquecendo e já unindo com os pensamentos de Agamben que:

[...] cada ato de governo se dirige para um fim primário e mais geral, mas terá necessariamente efeitos colaterais, que os estrategistas estadunidenses chamam de 
colateral damages e que podem significar a morte de muitos homens e a destruição de uma cidade inteira. A forma pura do ato de governo é um limiar de indistinção entre o geral e o particular, o primário e o secundário, o voluntário e o involuntário, o reino e o governo. A forma paradigmática de todo governo é o efeito colateral. Aqui me parece que há uma analogia com a estrutura do estado de exceção, que é também um limiar no qual se faz impossível distinguir entre reino e o governo, entre lei e a sua ausência, a anomia. Parece-me que, nessa perspectiva, o estado de exceção é algo assim como uma forma pura do ato de governo levada ao extremo (AGAMBEN, 2014, p. 35-36).

Destaca-se, portanto, outra linha de posicionamento de Agamben, o estado de exceção na qual pode ser visualizada no filme.

Em relação ao entendimento teórico sobre o estado de exceção recentemente pode ser observado uma pluralidade de pensadores dessa questão, com as mais variadas abordagens, cada um seguindo alguma singularidade em torno desta, basta notar o entendimento de François Saint-Bonnet (2001) em L'État d'Exception analisando problemáticas conceituais através de um estudo teórico e histórico; Nomi Claire Lazar (2009), professora da Yale-Nuss College, na obra States of Emergency in Liberal Democracy constatando os momentos preliminares e subsequente aos momentos de crise, relatando a desnecessidade da suspensão da norma nessa seara; Rafael Valim (2017) em Estado de Exceção: a Forma Jurídica do Neoliberalismo; Marie Goupy (2016) no livro L'état d'exception aduzindo sobre suas origens; Giorgio Agamben (2007) no feito Estado de Exceção, demonstrando-o no contexto das tecnologias de governo; entre outros pensadores.

Dentro dessa variedade de pensadores que percorrem o desenvolvimento teórico do estado de exceção, caminha-se para uma abordagem singular, desdobrando os pensamentos sobre tal temática em Giorgio Agamben, em razão dos conceitos que transitam com os campos do direito, da teologia e da filosofia, além de se relacionar com três importantes filósofos contemporâneos: Hannah Arendt, Carl Schmitt e Walter Benjamin. Percebe-se assim que o italiano convida por meio de sua filosofia reflexões sobre a política e acerca do direito na qual encontra uma provocação à contemplações da atualidade.

Sobre sua referida obra, o próprio Agamben (2014, p. 25-26) em um artigo científico mais recente que a obra denominada de Estado de exceção constrói um comentário aduzindo o seguinte:

Em meu livro Estado de exceção tentei oferecer algo assim como uma teoria do estado de exceção, mas desde que o terminei, me dei conta de que a teoria do estado de exceção não pode ser um fim ou um objetivo em si mesmo, senão que tem que estar inscrita em um conjunto mais amplo, no contexto das tecnologias de governo. Uma das teses do meu livro, talvez a mais óbvia, era que o estado de exceção concebido no passado como uma medida essencialmente temporal, converteu-se 
hoje em uma técnica normal de governo. Isto quer dizer que a compreensão do sentido do estado de exceção é inseparável de uma investigação sobre a natureza e a estrutura do governo. Neste caso, a maneira mais consequente de continuar minha análise do estado de exceção foi começar uma investigação arqueológica sobre o governo $[\ldots]$.

Pois bem, o filósofo italiano direciona seus estudos sobre estado de exceção demonstrando que este não pode ser presenciado exclusivamente como guerra civil, direito de guerra. Posto isto, parece interessante não deixar no anonimato, o campo como paradigma do pensador italiano, lembrando que para Agamben (2007, p. 173) “[...] O campo é apenas o local onde se realizou a mais absoluta conditio inhumana que se tenha dado sobre a terra".

Voltando para o passado, dando ênfase na exceção que em termos gerais seria gozada para demandar uma obediência a norma e não ser considerada como um viés do direito, pois na aplicação da exceção se destaca um espaço anômico.

Cabe ressaltar que o estado de exceção estava ao longo do passado usufruído como uma medida essencialmente temporal, conquanto no presente se tornasse uma técnica de governo usual.

Observe que essa linha de pensamento de Agamben pode ser presenciada no filme, nas cenas que aparece o pai da menina que faleceu, um poderoso tenente do exército turco (Yurdaer Okur), quando ele pede por exemplo para os guardas se distanciarem do desertor para ele ter uma conversa particular, nessa cena, ele executa o que poderia desempenhar um testemunho viável para salvar Meno.

Para Schmitt (2006) quem opta pelo estado de exceção é o soberano, lembrando que esse pensador realiza uma crítica a doutrina que defende a possibilidade de o estado de exceção ter como fonte a lei. Destarte, complementando o assunto, que Agamben (2004, p. 54) ressalta o pensador alemão Carl Schmitt compreendendo que ele não entende o estado de exceção sendo sinônimo de um estado anárquico.

À vista disso, Schmitt (2006) entende também que a exceção é o perigo que pode fazer com que o Estado deixe de existir, porque por meio desta o soberano pode suspender o Estado de Direito. Então, a exceção para Schmitt seria a suspensão total da ordem jurídica, cabe apenas ao soberano decretar a suspensão integral, pois é ele quem decide se estamos em perigo ou dentro de uma normalidade, fazendo chegar ao entendimento de que as decisões emanam da pura autoridade.

Requisitos como a necessidade e temporalidade devem ser presenciados no estado de exceção na visão agambeniana, visto que ao contrário se encontra um golpe de estado, isto é, uma ditadura. Por sua vez, o estado de exceção que se evidenciaria em algumas ocasiões de 
crise para manter a ordem, enxerga-se outra realidade, esse paradigma de governo se tornando mais habitual ao ponto de se observar como regra dentro das democracias, em suma, a exceção se torna regra (AGAMBEN, 2007).

Frente à isso e o que vai acontecer?

[...] o que ocorreu e ainda está ocorrendo sob nossos olhos é que o espaço
'juridicamente vazio' do estado de exceção (em que a lei figura - ou seja,
etimologicamente, na fição - da sua dissolução, e no qual podia portanto acontecer
tudo aquilo que o soberano julgava de fato necessário) irrompeu de seus confins
espaço-temporais e, esparramando-se para fora deles, tende agora por toda parte a
coincidir com o ordenamento normal, no qual tudo se torna assim novamente
possível (AGAMBEN, 2007, p. 44).

Bom, isso leva a realizar uma reflexão de que na verdade o estado de exceção é um espaço sui generis, onde o direito se torna indiscriminável em relação ao fato, cabendo à decisão pelo o que vai ser tutelar direitos e o que vai ser violência.

Ora, afirma-se que a exceção se encontra próximo da exclusão da norma, sabe-se, contudo, que ao mesmo tempo em que se encontra participando de uma relação de exclusão, não se pode afirmar o absoluto, melhor dizendo, a norma não está exclusa absolutamente em prol do sujeito, mas apenas singularmente.

Embora o estado de exceção que tem seu uso estabelecido para encerrar a violência, traz em si, o oposto, o iustitium $^{2}$, permitindo uma violência que não se prendem na legislação.

As competências dos poderes na qual cada um tem sua função típica está confusa, basta identificar o Poder Executivo exercendo atos que algumas vezes se confunde com o Poder Legislativo, ou até mesmo se presencia mediante os poderes governamentais uma ampliação na praxe do cotidiano, avista-se, em especial, o Poder Executivo e seus decretos com força de lei, contradizendo as competências típicas dos outros poderes. Pois então, “[...] uma das características essenciais do estado de exceção - a abolição provisória da distinção entre poder legislativo, executivo e judiciário [...]" (AGAMBEN, 2004, p. 19). Nesse diapasão, compreende-se cada poder exercendo a função típica do outro, aparentando legitimidade em seus desenvolveres.

No filme, permanece a ideia de confusão dos poderes em meios as atitudes do tenente que por ora se apresenta legislando, executando ou até mesmo pré-julgando. À título

\footnotetext{
${ }^{2}$ A declaração de interrupção ou suspensão do direito em searas temporais de necessidade por meio da vontade de um soberano se intitula no direito romano como iustitium. Infere, então, a contingência, isto é, algo que pode acontecer ou não (AGAMBEN, 2004).
} 
de exemplificação, note que quando Memo chega à prisão depois de ter sido julgado, ele é tratado pelos guardas de forma divergente dos outros detentos, a pedido do tenente houve considerações de tratamento diferenciadas, demonstrando ao redor do filme, cenas de violência.

O que se pode aduzir sobre essa cena, complementando essa ideia, é que Memo se encontra na figura do homo sacer, assumindo ainda o status de vida nua, mas por quais razões?

Ora, precisa inicialmente pensar que o personagem principal do filme tem uma ruptura do vínculo de cidadania, e aparenta ser uma vida que pode ser morta, uma vida que é vista exclusivamente em seu sentido biológico, mas não uma vida que pode ser sacrificada. Por ora, importa falar de modo complementar que Memo é considerado um criminoso para a população e que a origem do homo sacer é conectada ao criminoso, como Agamben (2014, p. 74) ressalta, estaria contida na "mais antiga pena do direito criminal romano" e o pensador adiciona o entendimento de que

\begin{abstract}
Aquilo que define a condição de homo sacer, então, não é tanto a pretensa ambivalência originária da sacralidade que lhe é inerente: quanto, sobretudo, o caráter particular da dupla exclusão em que se encontra preso e da violência à qual se encontra exposto. Esta violência - a morte insancionável que qualquer um pode cometer em relação a ele - não é classificável nem como sacrifício e nem como homicídio, nem como execução de uma condenação e nem como sacrilégio (AGAMBEN, 2010, p. 84).
\end{abstract}

Cabe aqui realizar uma analogia do filme à linha de pensamento de Agamben, posto que é pertinente dizer que Memo assume uma condição de vida nua como Walter Benjamin falaria, uma vida esquecida pelo direito, conceito este usufruído pelo próprio Agamben em sua produção acadêmica. Sobre isso, Castor (2013, p. 33) ensina que:

O homo sacer é um conceito-limite do direito romano que delimita o limiar da ordem social e da vida humana. Nele transparece a correlação entre sacralidade e a soberania. Ambas são estruturas originárias do poder político e jurídico ocidentais porque relevam os dois personagens que estão fora e acima da ordem: o homo sacer e o soberano. O homo sacer não só mostra a fragilidade da vida humana abandonada pelo direito, mas também, e mais importante, revela a existência de uma vontade soberana capaz de suspender a ordem e o direito. Tal poder só pode ser exercido desde fora da ordem e além do direito. O que homo sacer revela é a existência do soberano como figura essencial do direito ocidental e da sua ordem política. $O$ soberano existe porque tem o poder de decretar a exceção do direito, ou seja, suspender o direito para decretar a existência da vida nua. Só um poder soberano, que esteja fora da ordem e acima do direito, tem o poder de decretar a suspensão do direito para os outros. 
Ora, Memo é assim, pois sofre uma ruptura do vínculo de cidadania, qualquer regra processual de pessoa inimputável é desconsiderada no filme, equivocadamente tendo a contento um fim, punir e, por conseguinte matar, esse foi o caso dele. Memo torna-se assim, um sujeito excluído da ordem jurídica, contendo uma vida sem sentido, diga-se, uma vida nua desprovida de sentido.

\section{2 - MEMO COMO INIMIGO DE JAKOBS?}

Em 1985 em um congresso em Frankfurt, na Alemanha, foi a primeira vez que foi narrada a teoria do direito penal do inimigo, mas pode-se dizer que tal teoria conteve uma certa evolução ao longo do tempo. Naquela seara foi elucidada de forma divergente do que seria proposto no presente momento, naquela oportunidade inimigo seria única e exclusivamente o terrorista.

Por sua vez, o evento chamou atenção pelo fato de que Günther Jakobs, professor emérito de filosofia do direito e direito penal da Universidade de Bonn, pronunciava-a qualificando o direito penal sob o foco do inimigo, nesse instante o jurista também levantou tendências sobre o direito penal de exceção na qual era vigente na Alemanha. Diga-se, de passagem que essa fala em torno do inimigo, não seria uma sugestão política totalitária de Jakobs, pelo oposto, seria uma descrição de certas narrativas que acontecem dentro das democracias, ou melhor, do estado de direito.

Em relação a isso Prittwitz (2010, p. 915) comenta que:

[...] aquilo que em 1985 recebeu aplausos dos colegas, ficando, no entanto - por ser (demasiadamente crítico) - sem grande repercussão, em 1999 foi recebido pelos colegas com descrente espanto, em contrapartida sendo muito aplaudido por grupos que certamente não são do agrado de Jakobs. O que tinha mudado? Partindo da sua descrição crítica do estado de coisas, Jakobs tinha desenvolvido um modelo de direito penal parcial. Uma grande parte do direito penal alemão é, na opinião dele, direito penal do inimigo, coisa que Jakobs já tinha analisado em 1985. Porém, em 1999, ele diz: ela deve realmente ser direito penal do inimigo. Para se justificar esta guinada de 180 graus, Jakobs apresenta também cenários ameaçadores vindos com a globalização - não deixem ao Estado Democrático outra chance senão reagir com o direito penal do inimigo. É preciso dizer que é visivelmente a intenção de Günther Jakobs salvar a característica de Estado de Direito no direito penal do cidadão, dividindo o direito penal hoje em vigor num direito penal "do cidadão" e um "direito penal parcial do inimigo".

A partir de 11 de setembro, houve o atentado terrorista que aconteceu nos Estados Unidos e o próprio Jakobs começou a promover sua concepção teórica sobre o direito penal 
do inimigo, destacando cada vez mais a interpretação do terrorista como inimigo, mas por que como inimigo?

Observe que segundo ele, há cidadãos e inimigos, há delinquentes que são presenciados como inimigos, pois são considerados pessoas que não tem volta ao respeito do contrato social, são consideradas assim por ameaçarem o contrato social constantemente; contrariamente há o cidadão, aquele que não tente a ter expectativa em lesar no sentido de encerrar o sistema normativo vigente na sociedade, praticante assim, são os autores de crimes qualificados pela normalidade.

Depois de um tempo, Jakobs evolui seu pensamento compreendendo que não são apenas os terroristas que tem essa rotulação de inimigo, mas outras condutas são vistas como uma forma de se observar como inimigas da sociedade, principalmente por ameaçarem constantemente a sociedade. Pensada assim, deve-se negar a sua humanidade; à contramão há pessoas que comentem delitos menos graves, esses são os cidadãos que contém direitos e, por conseguinte, deveres, como são cidadãos e não inimigos deve respeitar a vontade da lei.

Ademais, o jus filósofo alemão fundamenta sua fala agregando o entendimento de que os imperativos de comportamento dependem do meio social, se preocupando assim e ao mesmo tempo destacando a figura do inimigo. Por ora, complementando essa ideia, inclusive cita que "o Direito Penal não se desenvolve na consciência individual, mas na comunicação. Seus atores são pessoas (tanto o autor como a vítima e como o juiz) e suas condições não são estipuladas por um sentimento individual, mas da sociedade" (JAKOBS, 2003, p. 94-95).

Essa proposta de se desenvolver a teoria do inimigo na praxe, embora não seja aceita sua prática pela maioria dos criminalistas pelas lesões ao Estado Democrático de Direito, se encontra em um estágio de reconhecimento científico entendendo que pode ser presenciada ao longo de diversos ordenamentos jurídicos. Portanto, por meio de Jakobs subentende que nem todos os criminosos são inimigos, alguns continuam sendo considerados cidadãos, essa ideia dele parte da fundamentação de Kant e de Hobbes que compreendiam que haviam criminosos que praticavam fatos normais estes vistos como cidadãos, de outro modo, haviam os inimigos que seriam aqueles que realizavam os fatos de alta traição. Portanto, há dois tipos de delinquentes um que vai ser considerado inimigo e o outro que continua sendo cidadão.

Para adicionar toda essa complexidade em torno das lições de Jakobs sobre o direito penal do inimigo, Moraes explana que: 
(a) o inimigo não pode ser punido com pena, sim, com medida de segurança; (b) não deve ser punido de acordo com sua culpabilidade, senão consoante sua periculosidade; (c) as medidas contra o inimigo não olham prioritariamente o passado (o que ele fez), sim, o futuro (o que ele representa de perigo futuro); (d) não é um Direito Penal retrospectivo, sim, prospectivo; (e) o inimigo não é um sujeito de direito, sim, objeto de coação; (f) o cidadão, mesmo depois de delinquir, continua com o status de pessoa; já o inimigo perde esse status (importante só sua periculosidade); (g) o Direito Penal do cidadão mantém a vigência da norma; o Direito Penal do inimigo combate preponderantemente perigos; (h) o Direito Penal do inimigo deve adiantar o âmbito de proteção da norma (antecipação da tutela penal), para alcançar os atos preparatórios; (i) mesmo que a pena seja intensa (e desproporcional), ainda assim, justifica-se a antecipação da proteção penal; (j) quando o cidadão (autor de um homicídio ocasional), espera-se que ele exteriorize um fato para que incida a reação (que vem confirmar a vigência da norma); em relação ao inimigo (terrorista, por exemplo), deve ser interceptado prontamente, no estágio prévio, em razão de sua periculosidade (MORAES, 2011, p. 197).

Ademais, se direcionando ao filme $O$ milagre na cela 7, Memo, personagem principal, dificilmente se classificaria nos moldes do inimigo se não tivesse ocorrido o acidente com a criança, isso pois é uma pessoa amada perante sua comunidade, mas a partir daquele momento da morte da criança ele passa de cidadão para inimigo, se encontrando dentro de um novo rótulo, como assassino de uma criança inofensiva.

Aliás, na cena ele aparece segurando a criança morta nos braços aparentando ter realizado o homicídio. A partir desse momento que ele é visto carregando a criança, ele é preso e aqui cabe algumas considerações que possa refletir o entendimento do inimigo de Jakobs.

Insta saber que o direito penal do inimigo se orienta por meio do funcionalismo radical, também conhecido como funcionalismo sistêmico, pretensão metodológica na qual é interpretada como radical nos moldes de prevenção geral e nela tem como escopo precípuo de ocasionar uma proteção por meio do direito penal ao próprio direito, ou melhor, o direito penal tutela a existência normativa para ocasionar a estabilidade social. Assim, "o Direito Penal não se desenvolve na consciência individual, mas na comunicação" (JAKOBS, 2003, p. 44), ele tem a qualidade de garantir a existência normativa a fim de preservar as instituições sociais.

Se fosse pensar em Memo embora ele é tratado como inimigo ao redor do filme, perceba que em sua essência ele não é, isto é, antes de ser visto como assassino de uma criança, ele não é o inimigo e é considerado como cidadão pelo fato de que ele seria incapaz de orientação normativa. Pode ser que o personagem na trama pela interpretação do Tenente até seja algo nesse sentido, mas tirando esse escombro do mundo das aparências e caminhando para o início do filme sabe-se que não é, Memo é uma pessoa que mesmo tendo 
problemas mentais não agiria com violência, como é mostrado ao longo da produção cinematográfica turca, há várias cenas que ele poderia ter se comportado dessa forma, mas tende a ter um comportamento tranquilo, um comportamento de paz (MILAGRE NA CELA 7, 2019).

Em contrapartida, Jakobs altera sua linha de pensamento assimilando que alguns crimes seriam privilegiados para tal feitores serem considerados inimigos e não mais apenas o terrorismo, são eles: “[...] no âmbito da criminalidade econômica, do terrorismo, da criminalidade organizada, no caso de delitos sexuais e outras infrações penais perigosas" (JAKOBS; MELIÁ, 2018, p. 34).

Nessa esteira, observe os diálogos de uma das partes do filme que mantém laços com esse contexto de Jakobs:

\footnotetext{
- O tribunal tomou uma decisão. De acordo com o testemunho e as provas reunidas, está decidido que o réu, Mehmet Koyuncu, é considerado culpado de assassinato de primeiro grau de Seda Altinkaya, será condenado à morte de acordo com os parágrafos 3 e 4 do artigo 450 do código penal turco [...] (MILAGRE NA CELA 7, $48 \mathrm{~min})$.
}

Essa parte do filme pode aparentar uma situação rotineira do direito penal, um suspeito de homicídio sendo considerado culpado e sentenciado. Por ora, realmente apenas aparenta legitimidade, mas não é, pois, Memo é visivelmente inimputável, não deveria ter sido interpretado com responsabilidade criminal pelo seu ato, levando em consideração sua característica biológica. Os próprios presos no filme debatem essa decisão do Poder Judiciário turco que para eles, foram injustas a punição.

Ora, se o direito penal tem a pretensão de punir fatos do passado, ou seja, fatos que já aconteceram, o direito penal do inimigo tem outro escopo, se encontra como meio preventivo, agindo até mesmo em quem ainda não realizou o delito, tutelando em prol de um perigo de fato que não aconteceu, mas que acreditam que vai acontecer.

Nesse sentido, Memo é presenciado como inimigo da teoria de Jakobs quando se direciona ao sistema processual penal ele passa por um sistema inquisitório em momentos que deveria seguir um sistema acusatório.

Logo, garantias constitucionais quando se aplicam ao caso do inimigo são desprezadas e com ele, por conseguinte o foi. É preciso recordar que mesmo Jakobs aludindo dois direitos, um voltado para o cidadão e outro para o inimigo, ele compreende que é muito complicado separar essas duas concepções jurídicas, não são direitos isolados (JAKOBS; 
MÉLIA, 2018). E isso que exatamente o filme demonstrou, haviam momentos que poderiam pensar que o personagem não estaria sendo visto como inimigo, mas quando se altera as cenas e o contexto ao longo da produção volta a mesma interpretação anterior, a do inimigo.

Em 1 hora e 41 min da produção acontece outra cena que chama atenção para levantarmos alguns posicionamentos de Jakobs sobre sua teoria do direito penal do inimigo. Um desertor que iria testemunhar a favor de Memo, pois no início da história quando a menina filha do tenente sofreu acidente, ele era a única pessoa que viu o acidente, foi executado pelo tenente, pai de Seda, criança falecida.

Poderia aqui, então, ter uma dedução extensiva da aplicação da teoria do direito penal do inimigo em Memo, pelos argumentos de que o filme transmite algumas cenas que esse personagem aparenta estar em guerra, precisando derrotar o inimigo de qualquer forma, no caso Memo.

No entanto, essa interpretação cabe apenas em momentos impares do filme, não é todo momento que ele é tratado nesse viés, outra cena que chama atenção nesse sentido é a que acontece aos 53 minutos do filme, a filha de Memo quer visita-lo, mas como é Memo o prisioneiro selecionado como inimigo do tenente por ora não teve direito de visita, embora todos os outros presos que fizeram algumas vezes crimes bem piores que o personagem, tinham o direito de visita.

Nesse diapasão, recorda-se que a supressão de garantias processuais se encontra como característica do direito penal do inimigo, porém o direito penal do inimigo não tem apenas uma característica, as penas desproporcionais e a antecipação da tutela penal são duas outras peculiaridades que deve ser levada em consideração.

Assim vendo todas as características, essa linha de entendimento de Jakobs se direciona ao Memo, mesmo havendo o saber de que "o Estado pode proceder de dois modos com os delinquentes: pode vê-los como pessoas que delinquem, pessoas que tenham cometido um erro, ou indivíduos que devem ser impedidos de destruir o ordenamento jurídico" (JAKOBS, 2018, p. 40).

No filme poderia ter havido apenas um erro de interpretação, aliás o suspeito foi achado segurando o corpo da menina morta e como ele contém deficiência intelectual não tinha a consciência de que aquele ato estava ocasionando sua culpa, mas esse erro de interpretação que imputa ao Memo a conduta delituosa faz com que ele se transforme em inimigo, pelo Tenente, pai da vítima, Memo não deveria ter direitos e sim lesões à sua integridade como foi demonstrado na parte inicial do filme quando ele chega a cadeia. 
Insta saber que Memo é interpretado pelos familiares de Seda e guardas da vítima como um assassino que cometeu um deslize em decorrência de sua deficiência, querem sua punição pelo fato ocorrido por quaisquer meios com aparência de legalidade. De toda forma, não conseguem eliminar o inimigo, ao final do filme esse personagem inclusive é ajudado a fugir com sua filha pelo diretor e guarda do presídio, na qual tinham o afeto pelo preso, morrendo outro detento em seu lugar.

\section{CONSIDERAÇÕES FINAIS}

O objetivo do presente artigo foi evidenciar por meio do filme Milagre na Cela 7 conceitos elucidados por Giorgio Agamben e Günther Jakobs, principalmente estado de exceção, homo sacer e direito penal do inimigo. Cabe ressaltar que o filme turco optado não foi uma escolha alheia e sim uma alternativa viável para gerar um recorte dos conceitos dos dois filósofos contemporâneos ilustrando realidades pontuais do cotidiano, linhas conceituais que aparentam ficar no passado se demonstra ao longo do filme que se perpetuam no presente, mas não de maneira integral.

Integralidade inclusive que representa a própria ideia tanto de Jakobs, como de Agamben, ambos compreendem, que algumas situações indesejáveis pensando na tutela pela vida humana acontecem dentro das democracias, ou melhor, do estado de direito mas não de forma integral. A explicação que se pode ter é no sentido de que a exceção não suspende integralmente o ordenamento jurídico, assim Agamben por meio de suas pretensões filosóficas, mais conhecidas através do projeto Homo Saccer, trouxe grandes contribuições para essa pesquisa. Aliás, o direito penal do inimigo não é uma proposta que se distancia do filme, mas uma descrição de algo envolvendo um dos personagens principal, conceito este que de fato se torna real em vários momentos.

Ademais, esse filme tem um conteúdo político e jurídico rico prezando nesses dois pensadores que narra a história de Memo, personagem na qual, é interpretada, as concepções teóricas desses dois pensadores. Além disso, as cenas desse filme são ambientadas pela exceção e pela criação de um inimigo. Portanto, Milagre na Cela 7 foi o privilegiado local para interpretação dos conceitos de Agamben e Jakobs nessa pesquisa.

As linhas de pensamento de Agamben desenvolvem um notável potencial de premissas que podem servir de molde para originais reflexões provocativas em torno da produção cinematográfica Milagre na Cela 7, sua filosofia pretendeu abrir os escombros que 
rondam o cotidiano político e jurídico. Nesse artigo, criou-se a capacidade de pensar no que pode acontecer, principalmente, nas bases jurídico-política e, especialmente, visualizando o contexto histórico de Memo.

Identificou-se que o estado de exceção era presenciado com os requisitos de necessidade e temporalidade, agora, na política contemporânea gozando do pensamento de Agamben, as exceções se tornam práticas de governo do cotidiano, ou melhor, nas democracias acontecem o estado de exceção como paradigma de governo. Isto significa dizer que o que era para ser exceção se torna regra e o filme muito bem demonstrou isso.

Sustentou-se, como hipótese que exceção e norma fluem uniformemente em Memo no filme Milagre na Cela 7 (2019), não havendo a suspensão total do ordenamento jurídico como Schmitt narra, mas fazendo com que a exceção se aparente dentro da legalidade, como também a aparência de legitimidade que convive o desrespeito à separação dos Poderes ocasionando assim a violência através do Direito. Nesses passos, é praticado a exceção ao longo de sua pena, havendo a suspensão de direitos e garantias fundamentais, observando-o como inimigo em que deve ser eliminado a qualquer custo.

No caso em tela, ressaltou-se que o Memo e direito penal do inimigo, podem se conectar ao longo do filme. Dessa forma, o personagem principal contém uma vida nua a partir do momento que ele é presenciado carregando a menina morta em seus braços, ali ele para de ser considerado cidadão e inicia uma interpretação social de inimigo. A partir desse momento, ele passa um drama que notoriamente é destacado o abandono dos direitos fundamentais e garantias à sua vida, tornando normal a suspensão destes, fazendo assim a exceção se tornar regra.

Finalmente, cabe concluir que, não se quer uma coação do saber, mas há que se ter um aprofundamento teórico desses pensadores não prezando por respostas, mas pelo fato que por meio deles abrirá a oportunidade de desenvolver pensamentos que poderão entender esse funcionamento do político e do jurídico demonstrando a essencialidade desse diálogo.

\section{REFERÊNCIAS}

AGAMBEN, G. Estado de Exceção. São Paulo: Boitempo, 2004.

AGAMBEN, G. Homo Sacer: O Poder soberano e a vida nua. Belo Horizonte, Editora: UFMG, 2007. 
AGAMBEN, G. Estado de exceção e genealogia do poder. Revista Brasileira de Estudos Políticos, Belo Horizonte, n. 108, pp. 21-39, jan./jun. 2014.

RUIZ, Castor M. M. Bartolomé. Homo sacer. O poder soberano e a vida nua. Cadernos IHU em formação, ano IX, no 45, 2013.

FOUCAULT, M. Em defesa da sociedade. $4^{\mathrm{a}}$ edição, São Paulo: Martins Fontes, 2005.

GIACÓIA JÚNIOR, O. Ética, direito e política em tempos de biopoder. Revista Jurídica FCV, v. 1, n. 1, p. 5-12, 2017.

JAKOBS, G. Sociedade, Norma e Pessoa: Teoria de Um Direito Funcional. São Paulo: Manole, Coleção Estudos de Direito Penal, v. 6, Tradução: Maurício Antonio Ribeiro Lopes, 2003.

JAKOBS, G.; MELIÁ, M. C. Direito Penal do Inimigo. $6^{\text {a }}$ edição. Porto Alegre: Livraria do Advogado, Ed., 2018.

LAZAR, N. C. States of Emergency in Liberal Democracies. New York: Cambridge University Press, 2009.

MILAGRE NA CELA 7. Direção: Mehmet Ada Öztekin. Produção: Saner Ayar; Sinan Turan. Turquia: O3 Turquia Medya, 2019. 1 DVD (132 min.).

PRITTWITZ, C. O direito penal entre direito penal do risco e direito penal do inimigo: tendências atuais em direito penal e política criminal. Trad. Helga Sabotta de Araújo e Carina Quito. Artigo n. 37. Direito Penal, v. 2. Organizadores: Alberto Silva Franco, Guilherme de Souza Nucci. São Paulo: Revista dos Tribunais, 2010.

RUIZ, C. M. M. B. O campo como paradigma biopolítico moderno. Cadernos IHU em formação, ano IX, n 45, 2013.

SAINT-BONET, F. L'État d'Exception. Paris: Puf, 2001.

SCHMITT, C. Teologia política. Tradução de Elisete Antoniuk. Belo Horizonte: Del Rey, 2006. 
VALIM, R. Estado de Exceção: a Forma Jurídica do Neoliberalismo. Editora Contracorrente, 2017.

VARGAS, D. C.; WEnTZ, M. T.; HORITA, F. H. D. S. Direito Penal do Inimigo. RJLB, Ano 3, no 5, p. 517-535, 2017.

ZAFFARONI, E. R. O inimigo no direito penal. Tradução de Sérgio Lamarão. $3^{\text {a }}$ edição, Rio de Janeiro: Editora Revan, 2014. 